\title{
Inmunización e inmunidad. Regreso a clases de inmunología.
}

\author{
Immunization and immunity. \\ Back to immunology class.
}

\begin{abstract}
El sistema inmunológico no sabe cuál es la mejor manera de atacar el SARS-CoV-2, por lo que genera anticuerpos contra muchas partes del virus con la esperanza de que algunos detengan la infección. Similar a lanzar dardos a un tablero de dardos con los ojos vendados. Algunos no lo harán-Golpee el tablero de dardos, muchos golpearán en lugares aleatorios, y un número muy pequeño golpeará la diana-. La prueba de anticuerpos neutralizantes mide los anticuerpos de la diana que realmente impiden que el virus

se una a las células y propague la infección. Dr. Sean Taylor, Ejecutivo GenScript
\end{abstract}

Agustín Zerón*

\begin{abstract}
C ada día el «volver a la normalidad» está más cerca al existir múltiples tipos de vacunas anti-COVID-19 que se distribuyen poco a poco en todo el mundo, y conforme avancen los esquemas de vacunación en la población, la inmunización se irá desarrollando en las personas. Las vacunas en sus diversas formas inducen inmunidad, pero la sola aplicación de una vacuna no es sinónimo de una automática inmunización. La inmunización es un proceso biológico para desarrollar inmunidad. Inmunidad es un término médico que describe el estado de tener suficientes defensas específicas para evitar una infección, enfermedad u otra invasión biológica no deseada. Al recibir una vacuna se estimularán las defensas del hospedero que producirán inmunidad.
\end{abstract}

En México sólo se ha vacunado a poco menos del 15\% de la población. Hasta el último reporte de la Secretaría de Salud, se han vacunado a poco más de $\mathbf{2 5}$ millones de personas en México: 14 millones 747,978 con el esquema completo y 10 millones 718,014 personas con nuevos esquemas. En nuestro país se aplican seis tipos de vacunas contra COVID-19: Pfizer-BioNTech (dos dosis), Oxford-AstraZeneca (dos dosis), Sputnik V (dos dosis), Sinovac (dos dosis), CanSino (una dosis), CoronaVac (dos dosis), y próximamente en los estados fronterizos la Johnson \& Johnson (una dosis).

Las revolucionarias vacunas Pfizer (mRNA-BNT162b2) y Moderna (mRNA-1273) pueden brindar protección contra la COVID-19, pero los resultados actuales no reflejan una completa «inmunidad esterilizante». Este tipo de inmunidad evita por completo que un patógeno causante de enfermedades como COVID-19 establezca una infección. La inmunidad esterilizante se diferencia de la inmunidad adaptativa en que esta última puede prevenir la enfermedad, pero aun así podría provocar una infección asintomática. La inmunidad esterilizante sigue siendo el santo grial de la investigación en las vacunas anti-COVID-19, aunque varios estudios en desarrollo son prometedores. Aun así, hay investigadores que se preguntan si realmente necesitamos una vacuna $100 \%$ efectiva para dejar a la COVID-19 detrás de nosotros y que sólo quede en los anales de las pandemias mundiales.

\footnotetext{
* Especialista en Endoperiodontología, Editor en Jefe de la Revista ADM. México. 


\section{EPITOPE Y EPÍTOME}

Los diferentes tipos de vacunas (RNA mensajero, subunidades proteicas o vectores virales) contra COVID-19 ayudan a desarrollar inmunidad contra el coronavirus SARS-CoV-2 que causa la enfermedad. Las vacunas estimulan la respuesta inmunológica sin haber tenido que contraer la enfermedad. Los diferentes tipos de vacunas actúan en diversas formas para brindar protección. Y como sucede igual que con otros tipos de vacunas, el organismo mantendrá un suministro de linfocitos $\mathbf{T}$ de «memoria», además de linfocitos B que recordarán cómo combatir en el futuro a ese mismo virus tan solo por reconocerlo con su determinante antigénico (epítopo que reconoce a la proteína Spike del coronavirus). El epitope (en inglés) o epítopo es una región molecular de los anticuerpos con la capacidad de reconocer específicamente a los virus o sustancias antigénicas, por eso los epítopos se conocen como determinantes antigénicos, que impiden que el virus se una a las células y propague la infección. Mientras las nuevas variantes del coronavirus sigan siendo reconocidas y ancladas por los epítopos, las vacunas y la respuesta inmune seguirán actuando con la misma eficacia. En México la variante Delta representa el 13\% de los virus circundantes. Esta variante es $65 \%$ más contagiosa y se propaga más rápido que el coronavirus original.

Un epítome es una palabra con significado muy diferente, es propiamente el resumen de una obra extensa, que describe lo fundamental o lo más importante. La importancia de los epítomes radica en que en muchas ocasiones permiten conocer un esbozo del contenido de obras perdidas. El epítome de esta pandemia para regresar a la «nueva normalidad» se escribirá cuando se logre alcanzar una inmunidad colectiva (o de rebaño). La inmunidad colectiva ocurre cuando una gran parte de la comunidad se vuelve inmune a una enfermedad, haciendo que sea poco probable la transmisión de persona a persona. Como resultado, toda la comunidad tiene inmunidad o protección, no sólo los que sean inmunes.

\section{INMUNOGENICIDAD}

La inmunogenicidad es la capacidad que tiene un antígeno o una vacuna para activar el sistema inmunológico para inducir una respuesta inmune. Por lo general, después de la vacunación el organismo demora algunas semanas en producir linfocitos Ty linfocitos B. Por consiguiente, es posible que una persona se infecte con el virus que causa la COVID-19 justo antes o días después de haber recibido la vacuna, y que la posibilidad de en- fermarse sería porque la vacuna no tuvo suficiente tiempo para activar al sistema inmunológico a fin de generar la protección necesaria.

El sistema inmunológico es una compleja red de órganos, tejidos, células, proteínas y moléculas interconectadas que tienen la misión de ser un mecanismo de defensa ante agentes extraños, patógenos o sustancias antigénicas. Mientras el sistema inmune esté activado, la inmunidad estará presente.

La inmunidad tiene tres tipos diferentes de acción: innata, adaptativa y pasiva. La primera se refiere a las barreras como la piel, mucosas y membranas que impiden la entrada de patógenos, también intervienen proteínas señalizadoras, fagocitos, células NK (natural killer), células dendríticas, neutrófilos y ciertas citocinas activadoras. La inmunidad adaptativa es adquirida y selectiva, se produce como respuesta del organismo ante una infección o después de la vacunación contra un agente específico para prevenir alguna infección futura del mismo agente patógeno. La inmunidad adaptativa podría durar toda la vida por la participación de mecanismos inmunológicos ahora bien conocidos. La inmunidad humoral es el mecanismo más importante en el que participan principalmente los anticuerpos y los linfocitos B, que básicamente son la fábrica de las inmunoglobulinas, capaces de neutralizar a los antígenos. Sólo cuando son activados por los linfocitos Th (colaboradores) empiezan a producir anticuerpos; primero la IgM y más tarde la IgG, IgA, IgE y la IgD para atacar a los agentes infectantes.

En general, la primera vez que nos exponemos a un patógeno, los linfocitos B tardan unos siete días en iniciar la respuesta inmune. Si el patógeno volviera a entrar, ya estarían esperándolos los anticuerpos junto a los linfocitos B de memoria inmunológica que actuarían en los primeros días de infección. La inmunidad celular es el tipo de inmunidad adaptativa mediada por los linfocitos T. Este tipo de células tienen receptores en su membrana que les permiten reconocer antígenos adheridos a la superficie de las células. Para actuar se necesita un complejo proceso de presentación del antígeno, que adhiere señales en la superficie de las células infectadas para que puedan ser 'reconocidas' por los linfocitos (CD4, CD8, supresores y de memoria). A pesar de las interesantes hipótesis actuales, todavía no hay conclusiones respecto a la inmunidad adaptativa contra el SARS-CoV-2.

La inmunidad pasiva se desarrolla a través de anticuerpos introducidos o inducidos para evitar una enfermedad al activar al mismo sistema inmunitario. La protección de la inmunidad pasiva es inmediata, previene una infección, 


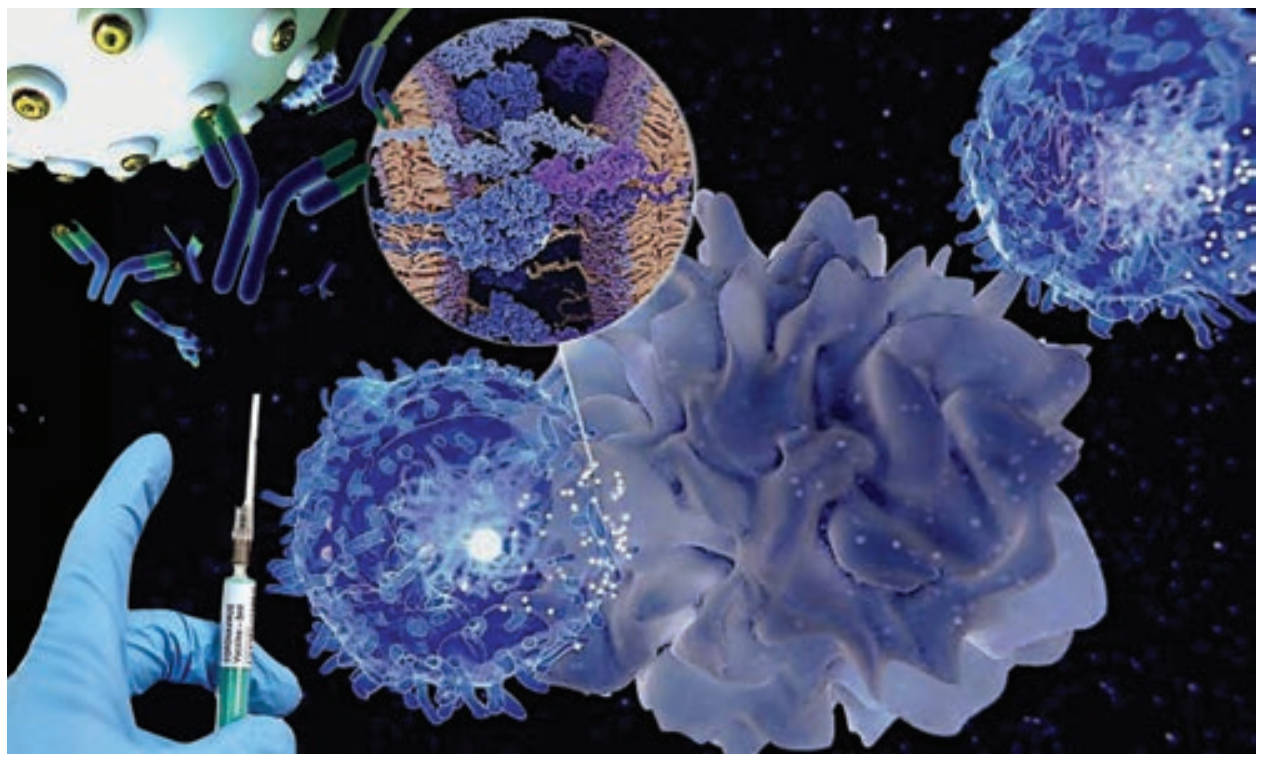

Figura 1:

Al recibir una vacuna se estimularán las defensas del hospedero que producirán inmunidad. La inmunidad es la respuesta biológica que genera una resistencia natural o adquirida frente a determinadas acciones patógenas de microorganismos o sustancias extrañas.

pero sólo dura semanas o meses. Si alguna persona se infectó por primera vez con el coronavirus que causa la COVID-19, su organismo podría tardar varios días o semanas en desarrollar la respuesta inmune para tratar de combatir a los virus a fin de vencer la infección.

Los linfocitos T (células T) son mediadores clave en la inmunidad adaptativa, la parte del sistema inmunológico capaz de generar un mecanismo de defensa duradero y específico contra bacterias o virus patógenos. La especificidad de la respuesta de las células T está relacionada con los receptores específicos de antígeno que expresan los TCR (T Cell Receptor). Si bien cada linfocito $\mathrm{T}$ se caracteriza por la expresión de miles de TCR idénticos, el repertorio global de TCR en el organismo es drásticamente variado, de modo que estas células pueden reconocer (y responder a) prácticamente cualquier intruso. De manera similar a las inmunoglobulinas expresadas por las células B, los TCR se generan somáticamente y su diversidad se obtiene mediante reordenamientos aleatorios de sus segmentos génicos. Las células T sólo reconocen los antígenos una vez que éstos se han procesado en péptidos y se han expuesto a la superficie de la célula diana, en una estructura de presentación de antígenos conocida como complejo mayor de histocompatibilidad (MHC clase I y II). La unión del complejo MHC-antígeno al TCR es el primer paso obligatorio para la activación de las células T. El MHC de clase I se puede encontrar en todas las células nucleadas. En condiciones fisiológicas, este complejo expone péptidos generados por el recambio normal de proteínas endógenas. Estos péptidos «propios» no desencadenarán la activación de los linfocitos T. Por el contrario, después de una infección viral, las proteínas virales también se procesarán en el citoplasma y luego se expondrán en la superficie celular, induciendo la activación de las células T (Figura 1).

Los linfocitos Th (auxiliares o colaboradores), después de su interacción con el MHC clase II en la APC (Antigen Presenting Cells), proliferan y se diferencian eventualmente modulando la actividad de otras células inmunes a través de la producción de las citocinas o por contacto de célula a célula. Hasta que encuentran al complejo MHC-péptido, las células tienen el potencial de diferenciarse en subgrupos, como Th1, Th2, Th17, Thf ( $T$ coadyuvante folicular), cada uno caracterizado por la secreción de una sustancia específica en el perfil de citocinas. Dado el papel crucial de los Th1 y Th2 en la respuesta inmune, está claro que el microambiente generado por las citocinas es fundamental en los procesos para emitir señales estimulantes en la respuesta inmunológica. En la actualidad, los estudios científicos sobre el epítopo o determinante antigénico del SARS-CoV-2 está liderando el camino para proporcionar la respuesta en cuanto al nivel de inmunidad obtenido a través de una vacuna o una infección previa.

Las citocinas (o citokinas) son un grupo de proteínas y glucoproteínas producidas por diversos tipos celulares que actúan fundamentalmente como reguladores de las respuestas inmunitaria e inflamatoria. Dentro del grupo de las citocinas se incluyen las interleucinas (IL), los factores 
de necrosis tumoral (TNF), los interferones (IFN), los factores estimuladores de colonias (CSF) y las quimiocinas. La «tormenta de citocinas» es una respuesta en la que se descontrola y se convierte en excesiva la producción de citocinas, tanto en cantidad como en calidad. La infección por coronavirus deja de ser una enfermedad local del aparato respiratorio y se transforma en una enfermedad sistémica que afecta a todo el organismo. Una característica similar a la periodontitis severa, también asociada con una alta producción de citocinas.

La inmunidad es protección, y la protección resulta ser una estrategia de contención, y por lo tanto de prevención. El precipitado regreso a clases y la señalización de un semáforo verde por decreto no detiene a la pandemia, y sí aumentan las condiciones y necesarias precauciones para evitar un rebrote epidémico, ya que los menores de edad pueden contagiar igual que un adulto. Por lo tanto, las condiciones para protegernos de un contagio por coronavirus deberán continuar, reforzando los cuidados en espacios cerrados y ventilados, en vista de que en la actualidad se reconoce la más fácil transmisión del SARS-CoV-2 a través de gotículas respiratorias y bioaerosoles, que serán el tema para nuestro próximo número. 